\title{
Challenges while Teaching English in the Social Science Classroom: A Bangladesh Perspective
}

\author{
Jurana Aziz \\ Assistant Professor in English \\ Department of Language Education \\ Institute of Education and Research \\ University of Dhaka \\ Bangladesh \\ Tel: 880-173-736-8120Ｅ-mail: zurana879@gmail.com
}

Received: December 14, 2016 Accepted: January 2, 2017 Published: January 8, 2017

doi:10.5296/ijele.v5i1.10567 URL: http://dx.doi.org/10.5296/ijele.v5i1.10567

\begin{abstract}
This paper written is based on the findings from a study conducted among the Social Science students of Advanced Level undertaking the English Language courses as Elective or compulsory and their mode of learning is Bengali other than few of these English courses. I have tried to explore some of the difficulties while teaching these students. Two groups of students were selected for experimental study and teaching was given following traditional approaches like CLT. Data were collected through classroom observation and questionnaires. Though the results found have some limitations, this paper aims at suggesting for the probable solutions to the problems and finally it opens a new window to face the learners with this type of challenging situation by adopting some of the innovative methods using the Humanistic approach of learning in English Language Teaching and Education.
\end{abstract}

Keywords: Challenges, Second language learners, Solutions 


\section{Mll Macrothink}

\section{Introduction}

English Language learners often face difficulties while learning it, especially if they are not exposed to this language for their everyday instruction. I had been observing students from the social science group who were learning English as one of their compulsory courses but their mode of learning for other courses is Bengali, which is their First language (L1). So they had been facing many problems while undertaking this course ACL-105. I tried to follow some instructions based on the idea of Humanistic approach and tried to implement few of the methods to solve the problems they encountered during learning.

In this paper I had focused on the problems they encountered first and then I had focused on the probable solutions to these problems. Finally I have shown how to meet the challenges of this kind of situation.

\section{Statement of the Problem}

Students of other groups like Social Science very often need to undertake some courses that are compulsory or elective beside their core courses. During that time it is found that they face different sort of problems that make them inhibited to learn a new language and they become unconfident to using that target language.

\subsection{Research Question}

What are the problems the social science students face while doing class with a English language teacher?

What are the possible reasons to the problems they encounter?

What are the probable solutions to the problems and how to solve those with present situation?

3. Methodology (Mixed method approach both qualitative and quantitative):

To conduct this research, I tried to follow the quantitative approach blending with the qualitative one. I took sample of 165 students in total, interviewed 10 teachers and observed at least 25 students while mostly by random sampling.

\begin{tabular}{|c|c|c|}
\hline Instrument/Tools & Sample & Sample Technique \\
\hline Questionnaire & 165 & Random Sampling \\
\hline Interview & 10 & Purposive \\
\hline Observation & 25 & Purposive \\
\hline
\end{tabular}




\section{Macrothink}

\section{Findings}

The challenges of the teacher while dealing with the social science students:

The problems of the learners that they encounter while learning I have found are;

\subsection{Lack of Interest}

The first problem that affects the learning environment is that in most of the cases they are not interested to learn or practice the target language that is English for those English courses. The chart shows that about $76 \%$ students are not interested about English learning, $14 \%$ students are interested and remaining $10 \%$ did not make any comment.

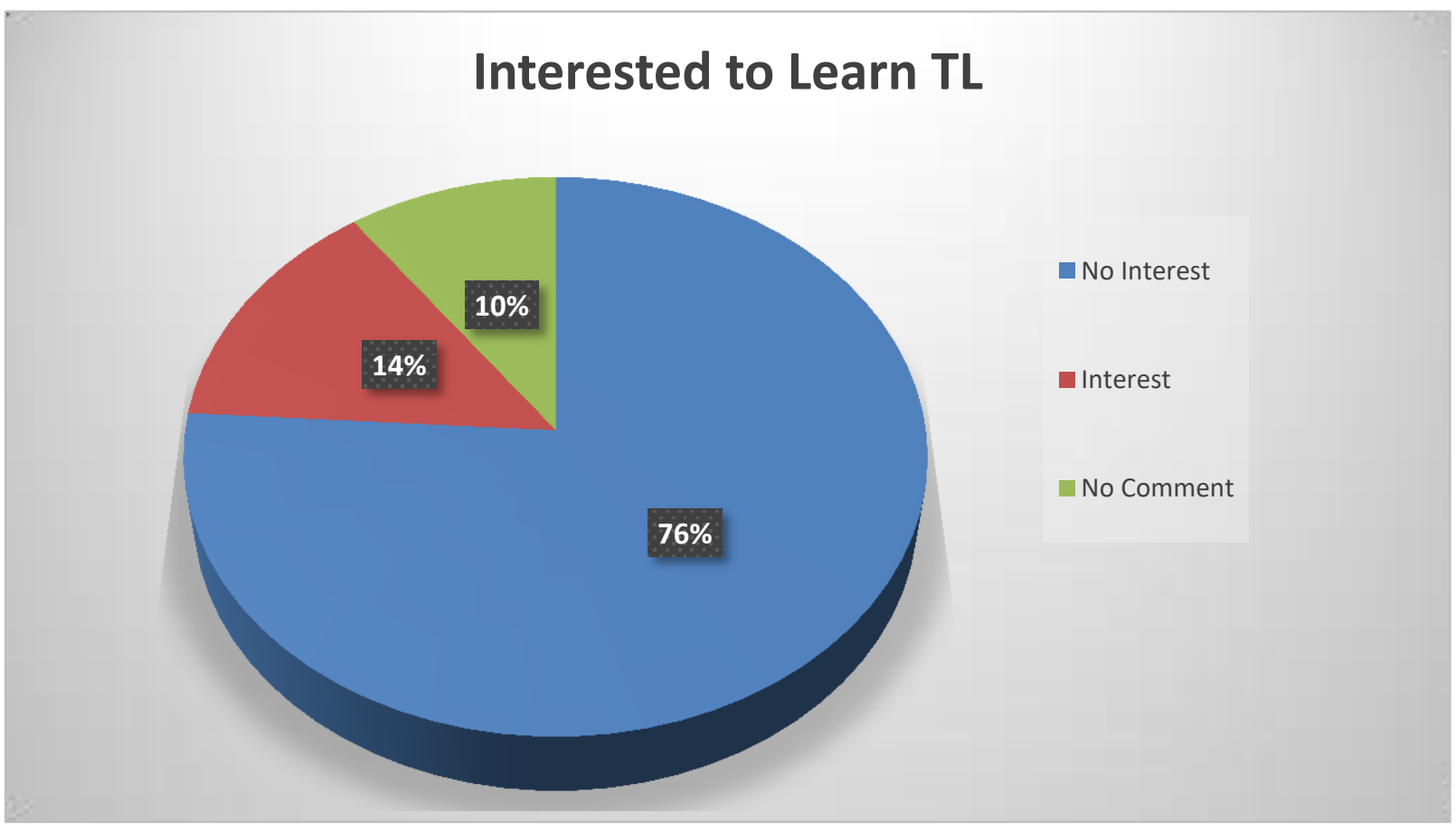

\subsection{Confusion about the Syllabus and Mode of Learning}

The problem that I encountered while teaching them is that most of them are using Bengali (that is their first language) as the mode of classroom instructions. They take notes on Bengali, follow the activities done in Bengali and their teachers are also using Bengali for giving them lectures. So they are not exposed to English that much. As a result they are confused while following every instruction in a new classroom where English is the Target language. Consequently they face problem to follow the syllabus written in English, they become confused to follow the instructions and always asking the teacher to change the mode of teaching. The following chart shows that $85 \%$ are confused totally, $12 \%$ can understand the syllabus and $3 \%$ did not respond. 


\section{Students' Difficulty With Syllabus}

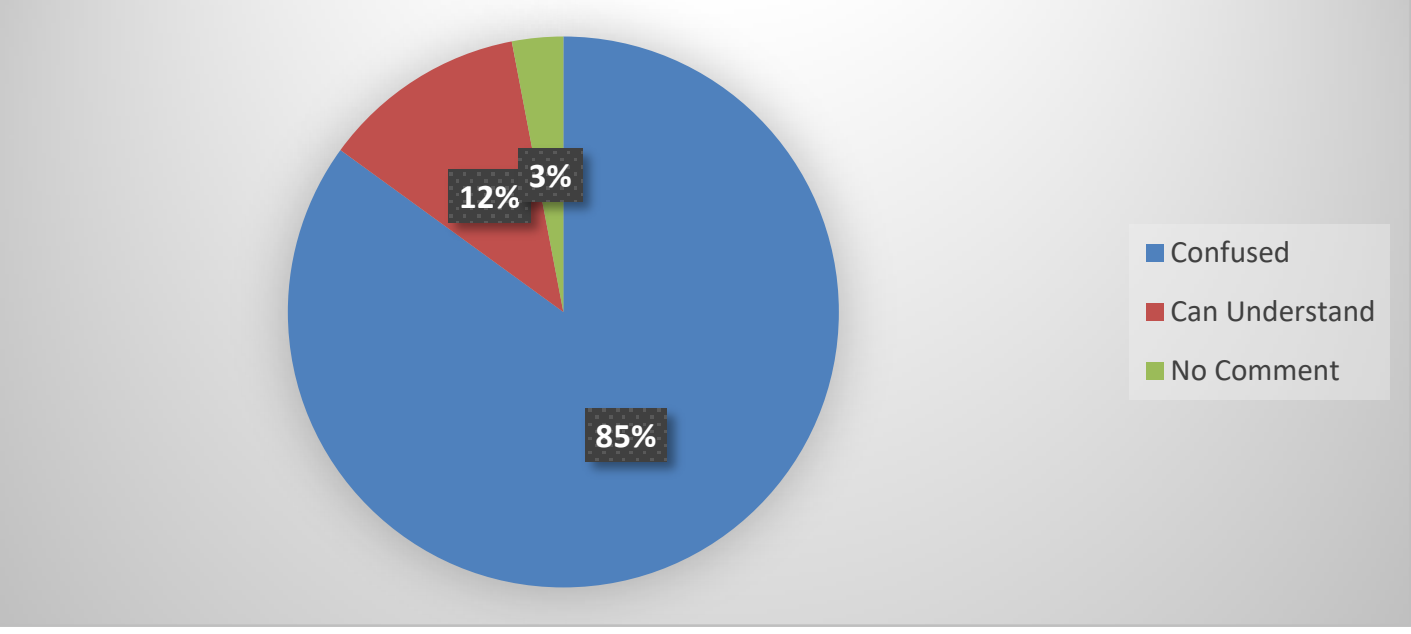

\subsection{Lack of Confidence}

The next problem that I found with the learners of Social Science group is they are inhibited to using English language as their main language of learning. They believe that they are not confident enough to using this language as it is not their main mode of earning at the higher level of education. About $95 \%$ learners think they will not be able to produce a successful sentence inside the classroom, about $5 \%$ students believe that they will not be able to speak fluent in front of the class.

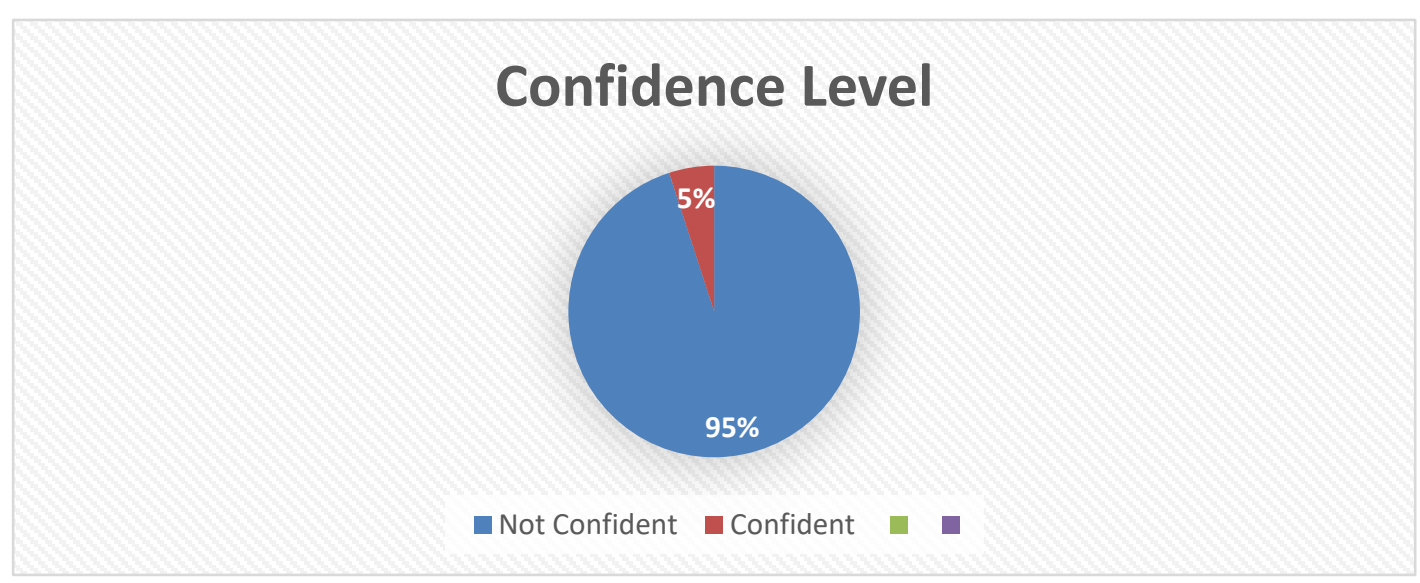

\subsection{Lack of Knowledge of Using the Four Basic Skills}

I found while teaching them that they are not aware of using the four basic skills of English language and their usage in different contexts. About $70 \%$ students faced problems with speaking, $15 \%$ with listening, $10 \%$ with reading, and $5 \%$ with writing. 


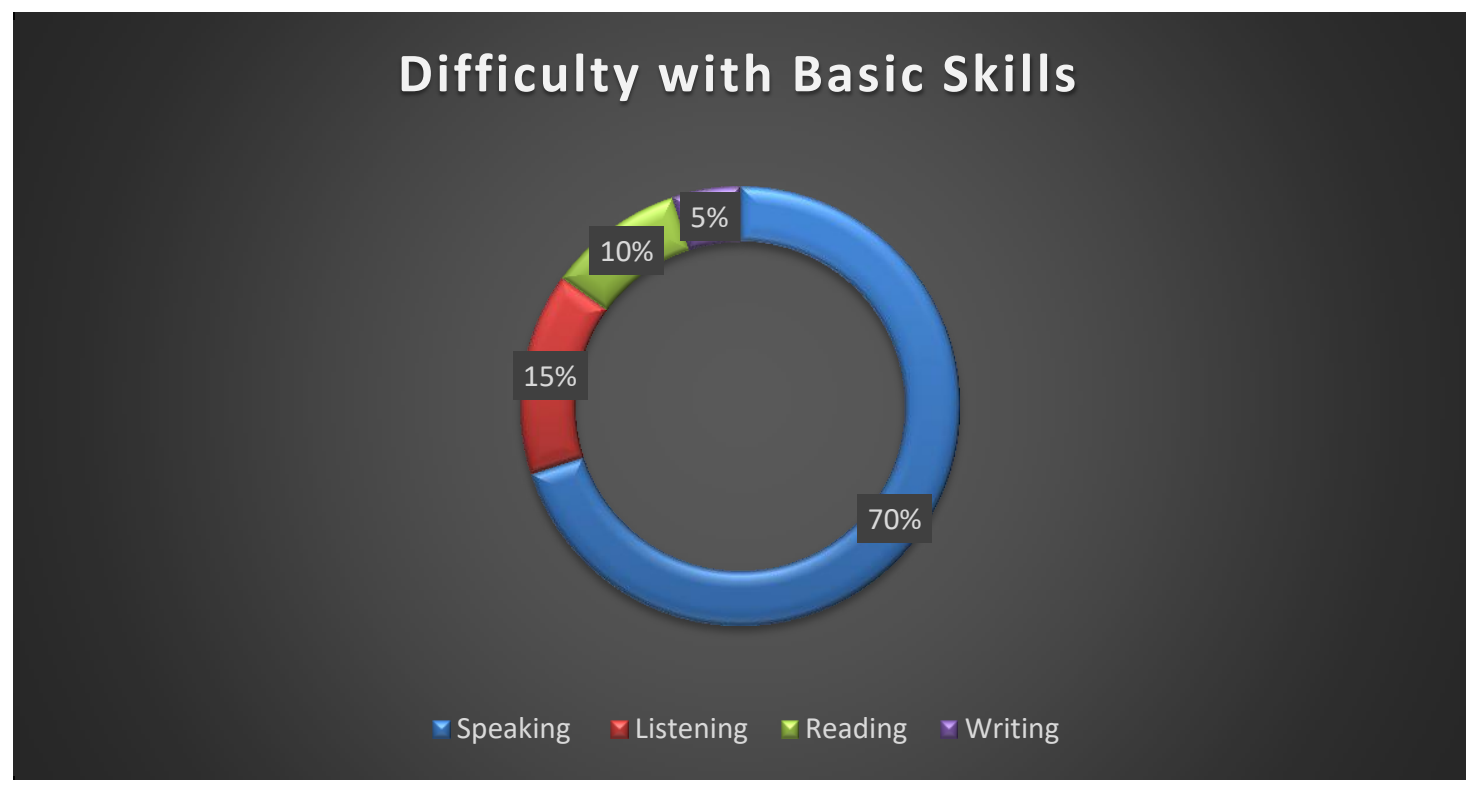

\subsection{Difficulties in Understanding the Syntactic Parts of English Language}

The next important problem is difficulties to understand the accents, transcription, intonation and grammatical components used in the classroom for teaching the target language. About $57 \%$ students are uncomfortable with grammatical parts, $27 \%$ with reading comprehension and $16 \%$ due to poor basic.

As English is not the main mode of learning their other courses, they feel less interest to learn the grammatical parts of this language and as a result they fail to use it in the classroom contexts.

\subsection{Frequent Switch of Codes Where Needed}

Though the instructions should be given in the target language (English) inside the classroom, in most of the cases the learners fail to follow it. So being a teacher I needed to switch codes from English to Bengali and it reduces the scope of using the target language in a full context. Findings:

$>70 \%$ are comfortable with delivering lecture in mixed language (Bangla and English)

$>30 \%$ are comfortable with English only

\subsection{The Intention of Only Passing the Exam}

As it is a sort of subsidiary course, the learners are only focused to get marks in the exam and thus they are found to have less interest to using English Language. They are only worried for attaining good marks in the exam and thus the learning process remains ignored. Findings:

$87 \%$ of the total students are worried of the passing of the exam

$>3 \%$ were found to achieve high level of proficiency in the future life. So to them English is only a language for accomplishing a course and nothing else. 


\section{The Recommendations for Solving the Problem}

I found some simple but effective ways to attract the learners of other groups to learn English as their target language and these activities will enhance their interest to accommodate with a new language that is a challenge for them too.

\subsection{Using Attractive Lesson Plan for the Language Classroom}

The social science students are new to know the methodologies applied inside an English language classroom. If the teacher could adopt some of the attractive steps in a lesson plan that would be used in the social science classroom then the learners would be motivated to learn the target language. So for them such activities are important to employ like;

\begin{tabular}{|l|l|}
\hline Use of linguistic component & Preferred type of activities \\
\hline While using a play & $\begin{array}{l}\text { Role play, simulation, jigsaw, stage } \\
\text { performance, comparing characters. }\end{array}$ \\
\hline While using a poetry & $\begin{array}{l}\text { Recitation, historical background, character } \\
\text { analysis, role play, information gap, poster } \\
\text { presentation. }\end{array}$ \\
\hline While using a novel & $\begin{array}{l}\text { Analysing the setting, theme, plot, } \\
\text { assignment works, group work, pair work. }\end{array}$ \\
\hline While using a paragraph & $\begin{array}{l}\text { Making them able to understand cohesive } \\
\text { ties, contexts, cause and effect, } \\
\text { argumentation, topic statements, thesis } \\
\text { statements. }\end{array}$ \\
\hline
\end{tabular}

\subsection{Giving Them Scope to Talk and Talk}

Increasing the student talk is a very effective way to face the problems inside a social science classroom. Being a teacher I gave them ample scopes to share their views with their peers and then exchange their views. This has helped them to break their inhibition to use English as a second language inside the classroom. They enjoyed the presentation session and finally they could be able to monitor their own lacings and this has also helped them to disclose a wide range of errors that they had been making through years. As a CLT teacher I always appreciated them to talk and encouraged them to continue talking.

\subsection{Adopting Humanistic Approach inside the Classroom}

Being motivated by the idea of the Humanistic Approach (Carl Rodgers, 1952), I employed this approach to motivate my learners. It was wonderful to see that whenever I appreciated them they could get more interest in learning a new concept and they could feel that English 


\section{Macrothink}

is just a language that can never be more powerful than their inner potentialities. It was found that students who are more nervous needed a little bit concentration from the teacher's side and when they are assured with it, they could project much better. In comparison to the other cases, I got my learners more confident at the end of the course while using English language.

\subsection{Building a Personal Relationship and Counselling the Learners}

It was also important that I found when I took the course that the learners needed positive reinforcement to get out of the groove. So I divided them into groups to focus on their mistakes and was counselling for them and it was astonishing that the group that was under careful supervision did better than the group that was overlooked.

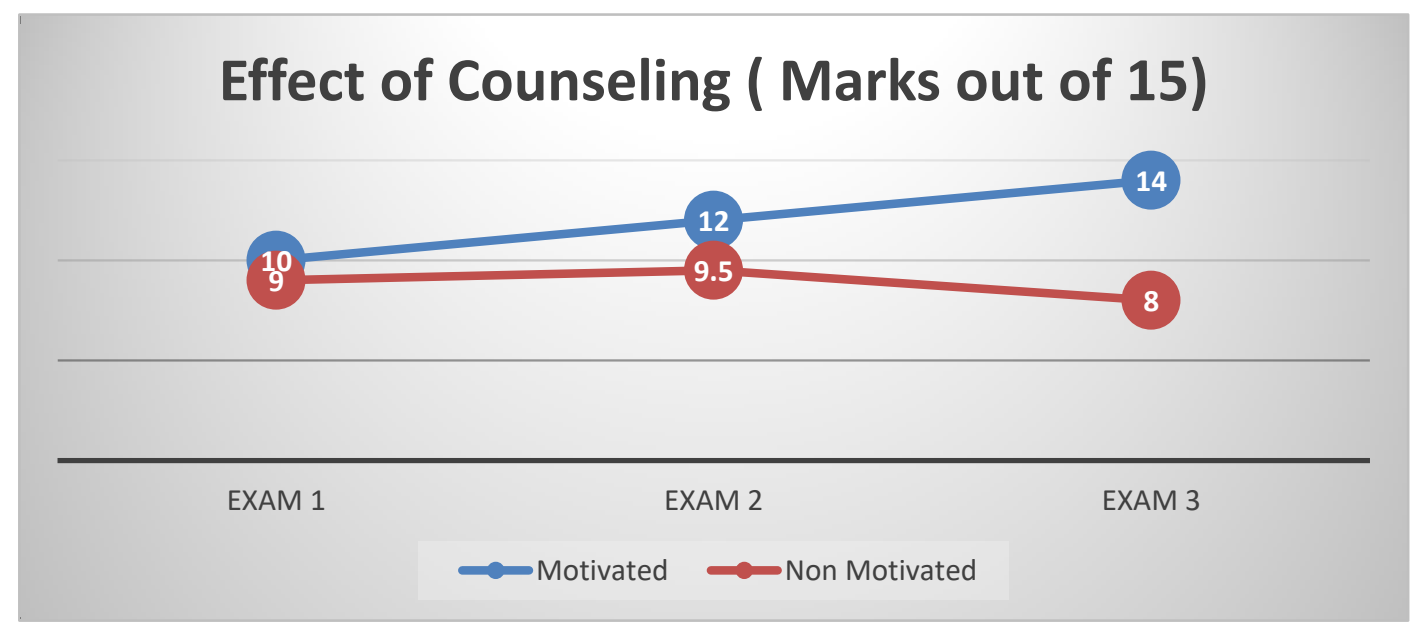

\subsection{Keeping Records of Their Performance}

This is very important to understand the overall situation and the expected needs of the learners. It will also help the teacher like us to prepare a need-based analysis to follow for the learners of other groups. From that analysis we would be able to take necessary steps for overcoming the problems encountered in a classroom.

\section{Conclusion}

To sum up, teaching of English to a social science classroom is very challenging one. The learners are not usually exposed to the Target Language and there are different levels of learners. The teachers should know the problems of the learners and try to take effective measures to overcome those. Then the pedagogical approaches will be also implemented according to the curriculum also.

\section{References}

Ahymadpoor, Z. (2004). Studying the Problems of EFL Teaching in High Schools. The Roshd ELT Journal, 18(71), 15-21.

Akbari, Z. (2014). The Role of Grammar in Second Language Reading Comprehension: Iranian ESP Context. Procedia - Social and Behavioral Sciences, 98, 122-126. 


\section{Ml Macrothink}

Akbari, Z., \& Tahririan M. H. (2009). Vocabulary Learning Strategies in an ESP Context: The Case of Para/medical English in Iran. Asian EFL Journal, 11(1), 40-62.

Aliakbari, M. (2005). The place of culture in the Iranian English text books in high school level. Journal of Pan-Pacific Association of Applied linguistics, 9(1), 163-179.

Amatobi, V. E., \& Amatobi, D. A. (2013). The influences of gender and attitude differences to students' achievement. American Journal of Research Communication.

Bada, E., \& Okan, Z. (2000). Students' language learning preferences. TESL-EJ, 4(3).

Bagheri, H. (1994). A Profile for Teaching and Teaching English in Pre-university Schools of Sistan and Baluchestan: Problems and Solutions (Unpublished M. A. Thesis), Shiraz University, Shiraz.

Carver, D. J., \& Dickinson, L. (1982). Learning to be self-directed. In G. S. E. In M. Geddes (Ed.), Individualization. London: Modern English Publications.

Chastain, Kenneth. (1988). Developing Second Language Skills, Theory and Practice. United States of America: Harco urt Brace Jovanovich, Inc.

Crystal, D. (1997). English as a Global Language. Cambridge University Press: Cambridge.

Cunningsworth, A. (1995). Evaluating and Selecting EFL Teaching Materials. London: Heinemann.

Dooly, M. (2008). Constructing Knowledge Together. Extracted from Telecollaborative Language Learning. A guidebook to moderating intercultural collaboration online (pp. 21-45). Bern: Perter Lang.

H. Babai Shishavan, V. Melbourne. (2010). The Relationship between Iranian English Language Teachers' and Learners' Gender and their Perceptions of an Effective English Language Teacher. English Language Teaching, 3(3), 3-10.

H. D. Brown. (1973). Affective variables in second language acquisition. Language Learning, 23, 231-244.

J. Edge. (1996). Cross-cultural paradoxes in a profession of values. TESOL Quarterly, 30, 930.

J. H. Schumann. (1975). Affective factors and the problem of age in second language acquisition. Language Learning, 25(2), 209-235.

L. Dickinson, \& D. Carver. (1980). Learning how to learn: Steps towards selfdirection in foreign language learning in schools. ELT Journal, 35(1), 1-7.

M. Behroozi, \& A. Amoozegar. (2014). Challenges to English Language Teachers of Secondary Schools in Iran. Procedia - Social and Behavioral Sciences, 136, 203-207.

McGrath, I. (2002). Materials evaluation and design for language teaching. Edinburgh University Press: Edinburgh. 


\section{Macrothink}

Moradi, F. (1996a). An Investigation into the Problems of Teaching \& Learning English in Tehran Province. (Unpublished MA thesis), Shiraz University, Shiraz.

Naiman, N., Frohlich, M., Stern, H., \& Todesco, A. (1978). The good language learner. Toronto: Ontario Institute for Studies in Education.

Oxford, R. (2001). Integrated Skills in the ESL/EFL Classroom. ERIC Digest. ED456670.

Saadat, M. (1995). An Investigation into the Problems of Teaching and Learning English in the Guidance and High Schools of Fars Province. (Unpublished M. A. Thesis), Shiraz University, Shiraz.

Stern, H. H. (1983). Fundamental concepts of language teaching. Oxford: OUP.

Z. Eslami. (2010). Teachers' voice vs. students' voice: A needs analysis approach to English for academic purposes (EAP) in Iran. English Language Teaching, 3(1), 3-11.

Zanganeh, M. (1995). Analysis of Problems of Teaching and Learning English in the High Schools of the Kermanshah Province. (Unpublished M.A. Thesis), Shiraz University, Shiraz.

\section{Copyright Disclaimer}

Copyright for this article is retained by the author(s), with first publication rights granted to the journal.

This is an open-access article distributed under the terms and conditions of the Creative Commons Attribution license (http://creativecommons.org/licenses/by/3.0/). 